\title{
ЗООЛОГІЯ
}

УДК 598.1:591.5

doi: $10.25128 / 2078-2357.19 .2 .3$

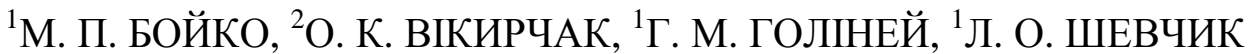 \\ ${ }^{1}$ Тернопільський національний педагогічний університет імені Володимира Гнатюка \\ вул. М. Кривоноса, 2, Тернопіль, 46027 \\ ${ }^{2}$ Національний природний парк «Дністровський каньйон» \\ вул. Степана Бандери, 5 б, Заліщики, Тернопільська область, 48604 \\ e-mail: halyna.holiney@gmail.com
}

\section{ХАРАКТЕРИСТИКА ЧИСЕЛЬНОСТІ ТА ПРОСТОРОВОГО РОЗПОДІЛУ ПОПУЛЯЦЙ ЗЕЛЕНОЇ ЯЩІРКИ (Lacerta viridis Laurenti, 1768) НА ТЕРИТОРІї НПП «ДНІСТРОВСЬКИЙ КАНЬЙОН»}

Досліджено сучасний стан популяцій зеленої ящірки (Lacerta viridis Laurenti, 1768) в межах території Національного природного парку «Дністровський каньйон». Вивчено чисельність та просторову структуру популяцій виду в різних біотопах на основі багаторічних фенологічних спостережень згідно програми Літопису природи парку та власних досліджень авторів. Наведено дані про просторовий розподіл виду на території парку за останні 6 років. Проведено аналіз чисельності популяцій ящірки зеленої в різних біотопах та особливостей впливу основних екологічних факторів на стан цих популяцій.

Ключові слова: Lacerta viridis Laurenti, екологія, популячія, біотоп, НПП «Дністровський каньйон».

Фауністичні дослідження є основою зоологічної науки. Саме достовірні відомості про видовий склад, спосіб життя, чисельність, поширення, особливості розмноження $є$ не тільки вихідними даними подальших зоологічних, еволюційних й екологічних досліджень, але й становлять основу природоохоронної діяльності, яка базується на аналізі стану ресурсів тваринного світу. Вивчення змін таких показників як чисельність і структура популяцій наземних хребетних залишається важливим завданням сучасної екології.

Зелена ящірка (Lacerta viridis Laurenti, 1768; Reptilia, Squamata) - один із вразливих видів рептилій української герпетофауни. Цей вид є об'єктом багатьох екологічних досліджень, зокрема спрямованих на вивчення структури популяцій, біотопного розподілу, у тому числі в межах природних територій, які охороняються, а також територій, що зазнають помітної антропогенної трансформації $[11,12]$. Одним із мало вивчених показників залишається чисельність локальних популяцій зеленої ящірки в межах іiі ареалу. На особливу увагу заслуговують чинники, що об' єктивно впливають на подібні зміни і процеси $[10,12]$.

Головним завданням нашого дослідження було виявлення особливостей структури популяцій зелених ящірок та специфіки біотопного розподілу виду в Тернопільському Придністер'ї. 


\section{Матеріал і методи досліджень}

Для проведення популяційно-екологічних досліджень нами були використані стандартні методики польового збору матеріалу та аналізу одержаних результатів, які використовуються в демекології.

Обліки проведені у 6 пунктах, що охоплюють різні типи природних та трансформованих біотопів. Підрахунок чисельності виконано маршрутним методом візуального спостереження за кількістю особин на маршруті (2-3 км) в перерахунку на 1 км [9].

В основу роботи покладено польові дослідження, здійснені протягом 8 експедиційних виїздів, які проводилися у квітні - серпні 2018 року та дані регулярних фенологічних спостережень НПП «Дністровський каньйон».

Планові обліки чисельності L. viridis проводились на двох комплексних фенологічних маршрутах (КФМ) які охоплюють різноманітні біотопи [3].

КФМ 2012-001 Дністер - Пустельня - Джурин: острови;

I ділянка - берег р. Дністер (1 км), доступні для спостережень біотопи - p. Дністер,

II ділянка - крутий схил річкової долини (0,5 км), доступні для спостережень біотопи лучно-степові угруповання, сосновий ліс;

III ділянка - автотраса, листяний ліс (0,5 км), для спостережень біотопи чагарникові зарості з переважанням жарнівцю віничкового;

IV ділянка - початок лісу - урочище Пустельня (1,5 км), доступні для спостережень біотопи - зрілий дубово-грабовий ліс, травертинова скеля;

$\mathrm{V}$ ділянка - p. Джурин (2 км), доступні для спостережень біотопи - заліснена заплава;

VI ділянка - с. Устечко (1 км), доступні для спостережень біотопи - штучна екосистема с. Устечко.

КФМ № 2012-002 Городок - Добрівляни:

I ділянка - Городоцька (2 км), доступні для спостережень біотопи - p. Дністер, штучна екосистема села;

II ділянка - урочище Печеніги (2 км), доступні для спостережень біотопи - p. Дністер, пасовище, глинисті ерозійні урвища;

III ділянка - с. Деренівка - с. Криве (3 км), доступні для спостережень біотопи p. Дністер, лісо-чагарникові зарості, лучно-степові ділянки, кам'янисті осипи, вапнякові скелі;

IV ділянка - колишня турбаза - с. Добрівляни, доступні для спостережень біотопи - лісочагарникові зарості, ділянки відновлення природної рослинності.

\section{Результати досліджень та їх обговорення}

L. viridis перебуває під особливою охороною Бернської конвенції (додаток II) та занесена до Червоної книги України (2009).

Ареал L. viridis: охоплює Середню та Південну Європу, південний захід Східної Європи та північно-західну частину Малої Азії. В Україні трапляється мозаїчно в степовій i лісостеповій зонах майже виключно Правобережної України, а також у Закарпатті [2].

В біогеоценозах зелена ящірка, як більш крупний вид, є не тільки консументом 2-го та 3го порядків, а виступає ще й як хижак-консумент 4-го порядку (у раціонах присутні хребетні консументи 2-3 порядків). Співвідношення кормових об`єктів у живленні виду має певні відмінності у вологих та сухих біотопах [4].

Зелена ящірка є стенотопним видом, який надає перевагу лише 2-3-м біотопам, i тому $є$ дуже вразливим видом. У місцях, де угруповання L. viridis залишаються чисельними, вона, безумовно, відіграє значну роль в екосистемах [6].

За даними Л. Ю. Соболенко, у межах Західного Поділля L. viridis виявлена виключно в районі Західно-Подільського Придністров'я по долині Дністра та його приток $[7,8]$, тому результати нашого дослідження дозволяють досить повно оцінити сучасний стан популяцій $L$. viridis у цьому регіоні (рисунок). 
Наші дослідження вказують на те, що популяції зеленої ящірки території НПП «Дністровський каньйон» трапляються в різноманітних біотопах, але найчастіше місця знахідок пов'язані із чагарниками. Біотопи зеленої ящірки можна поділити на дві групи: 1) типові й 2) мало типові, у яких зелені ящірки зустрічаються спорадично або випадково (фото).

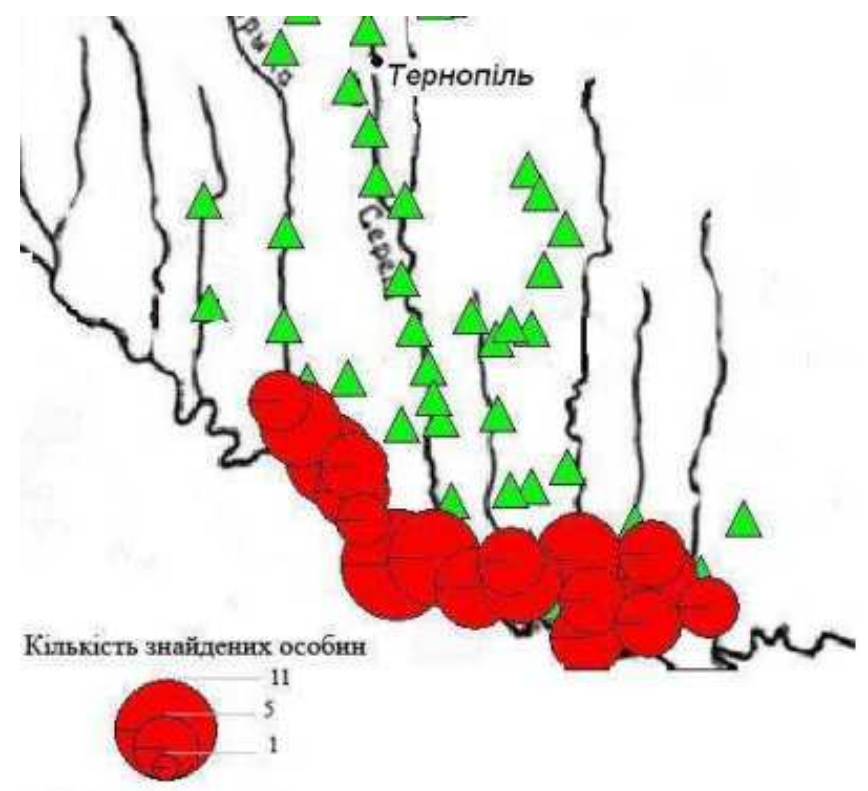

Відсутність знахідок

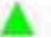

Рисунок. Місця поширення і кількість знайдених особин L. viridis на території НПП «Дністровський каньйон» [7]

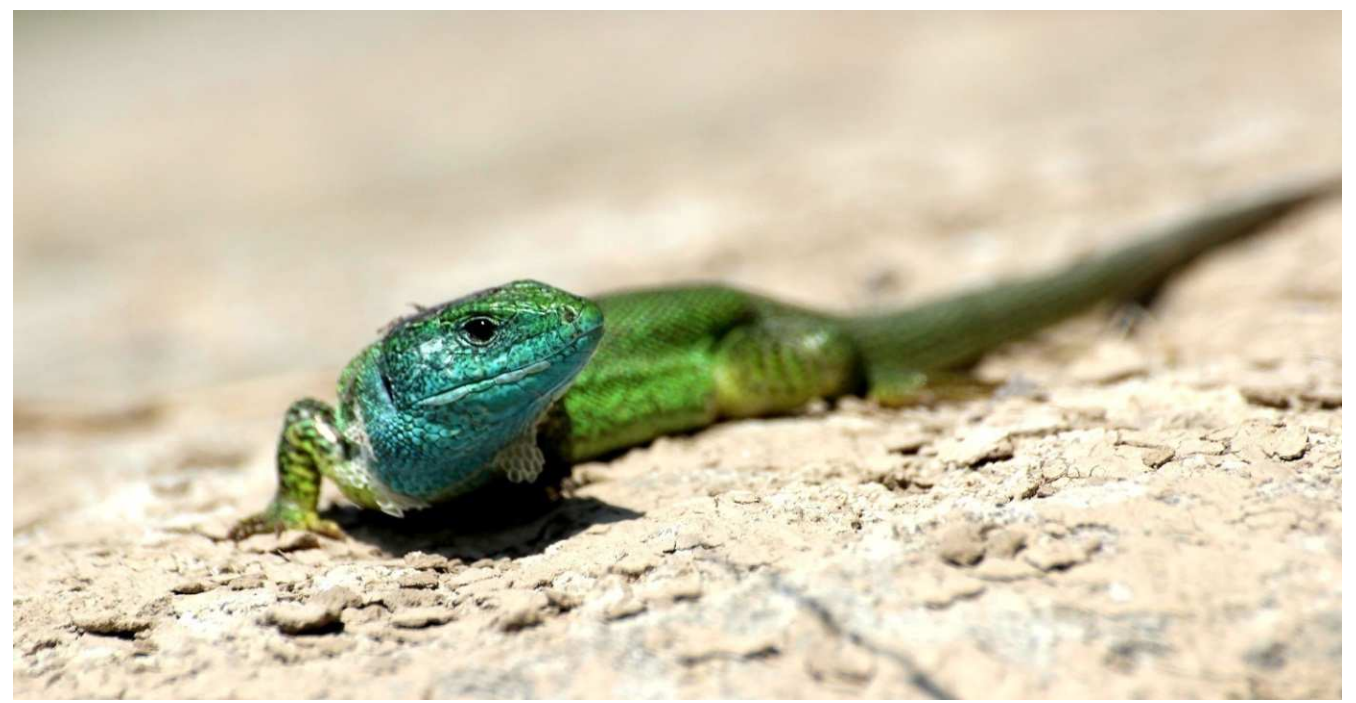

Фото. Ящірка зелена, ок. с. Добрівляни, Заліщицького р-ну, відкритий схил p. Дністер. 24.04.2018 р. (фото з архіву НПП «Дністровський каньйон»)

У результаті проведених досліджень встановлено, що в типових біотопах (лісові галявини, узлісся, схили річкових долин) L. viridis $\epsilon$ найбільш чисельним видом плазунів. Найвищу чисельність популяцій ящірки зеленої виявлено на південних схилах р. Дністер. 
Згідно з попередніми дослідженнями науковців, оселища ящірки зеленої приурочені до лісочагарникових заростей широколистяних та мішаних лісів і до ділянок з густим травостоєм лучно-степової рослинності та чагарниками глоду й шипшини, де чисельність виду коливається від 20-50 ос./км до 30-50 ос./км; дещо меншою вона $\epsilon$ на кам'янистих осипах та вапнякових скелях (6-11 ос./км) [8].

Так, на III ділянці КФМ №2012-002 Городок - Добрівляни особини дослідженого виду зустрічались 3 частотою 1 екз. на 100 м (10 ос. на маршруті) (табл. 1). За сприятливих погодних умов на цій ділянці фіксувалося більше 30 особин [3]. На лучино-степових ділянках околиць с. Голігради було зафіксовано багато особин дослідженого виду. На кам янистих осипах та вапнякових скелях в околиці смт. Мельниця Подільська за період дослідження на маршруті фіксували 1 особину.

В інших біотопах чисельність зеленої ящірки значно менша, проте стабільно фіксується хоча б декілька екземплярів на узліссях (околиці с. Добрівляни - 4 особини на маршруті), а також у заплавних біотопах (околиці с. Монастирьок - 1 особина). На території НПП «Дністровський каньйон» зелена ящірка спостерігається і в антропогенізованих умовах, на дорогах, поряд із будівлями. Окремі особини заходять у населені пункти, що розміщені неподалік природних оселищ.

Таблиия 1

Місця виявлення ящірки зеленої у НПП «Дністровський каньйон» (дані за 2018 рік)

\begin{tabular}{|c|c|c|c|c|}
\hline № & Дата & Місце фіксування & Координати & $\begin{array}{c}\text { Кількість } \\
\text { зафіксованих } \\
\text { особин }\end{array}$ \\
\hline 1. & 5.04 .18 & Урочище Самотия, околиці с. Голігради & $\begin{array}{l}48^{\circ} 36^{\prime} 4.09 " \text { "пн.ш. } \\
26^{\circ} 8151.21 " \text { сх.д. }\end{array}$ & $+\infty$ \\
\hline 2. & 7.04.18 & $\begin{array}{c}\text { околиці смт. Мельниця Подільська, урочище } \\
\text { Бавки }\end{array}$ & $\begin{array}{l}48^{\circ} 36^{\prime} 4.09 " \text { пн.ш. } \\
26^{\circ} 8 \text { '51.21"сх.д. }\end{array}$ & 1 \\
\hline 3. & 2.05 .18 & околиці с. Добрівляни, дорога до колишньої т/б & $\begin{array}{l}48^{\circ} 40^{\prime} 36.86 " \text { "пн.ш. } \\
25^{\circ} 45^{\prime} 53.18 " \text { сх.д. }\end{array}$ & 10 \\
\hline 4. & 12.05.18 & $\begin{array}{l}\text { ококлиці с. Гіньківці, схил р. Тупа, деградовані } \\
\text { лучно-степові фітоценози }\end{array}$ & $\begin{array}{l}48^{\circ} 46^{\prime} 17.55^{\prime \prime} п \text { пнш } \\
25^{\circ} 45^{\prime} 24.67 " \text { сх.д. }\end{array}$ & 1 \\
\hline 5. & 6.07 .18 & околиці с. Добрівляни, дорога до колишньої т/б & $\begin{array}{l}\text { 48॰40'36.86"пн.ш. } \\
\text { 2545'53.18"сх.д. }\end{array}$ & 4 \\
\hline 6. & 6.09 .18 & околиці с. Монастирьок, берег р. Серет & $\begin{array}{l}48^{\circ} 43^{\prime} 52.55^{\prime \prime п н . ш . ~} \\
25^{\circ} 52^{\prime} 1.07 " \text { сх.д. }\end{array}$ & 1 \\
\hline 7. & 13.09 .18 & берег Дністра, нижче колишньої т/б & $\begin{array}{l}48^{\circ} 40^{\prime} 25.03 " \text { "пн.ш. } \\
25^{\circ} 47^{\prime} 32.30^{\prime \prime} \text { сх.д. }\end{array}$ & $\infty *$ \\
\hline 8. & 27.09 .18 & околиці с. Добрівляни, дорога до колишньої т/б & $\begin{array}{l}\text { 4840'36.86"пн.ш. } \\
\text { 2545'53.18"сх.д. }\end{array}$ & 1 \\
\hline
\end{tabular}

Примітка: * переважно ювенільні особини

За результатами проведених досліджень виявлено важливе значення рослинності в біотопному розподіл популяцій дослідженого виду. Зелена ящірка трапляється на ділянках узлісся, де наявні злаково-чагарникові, злаково-різнотравні або злаково-осокові асоціації $з$ високим помірно щільним травостоєм та 3 достатньою кількістю сховищ. Наявність підстилки не обмежує розселення ящірок, хоча вони віддають перевагу ділянкам, де підстилка мало потужна. Зелені ящірки уникають ділянок, де в складі рослинності багато представників Губоцвітих (Lamiaceae) та деяких інших рослин, зокрема амброзії полинолистої (Ambrosia artemisiifolia). Зелена ящірка трапляється в біотопах з окремими представниками Айстрових (Asteraceae). Загалом встановлено, що цей вид плазунів віддає перевагу асоціаціям із домінуванням злаків та осокових.

Просторова структура популящій. Просторовий розподіл особин зеленої ящірки залежить від характеру біотопів. На території НПП «Дністровський каньйон» чітко 
простежується наявність двох типів просторової структури популяцій: плямиста (агрегована) та стрічкоподібна (витягнута пляма). Виявлено й певні варіації основних структур: щільноплямиста 3 відстанями від 10-15 до 50-100 м між групами, плямиста 3 великими відстанями (до 2 км), стрічкоподібна 3 відстанями між субпопуляціями до 1 км, а також агрегаційно-мозаїчна при найбільшій щільності поселення ящірок. На вологих луках зафіксовано нерівномірноплямисте розселення із відстанями між особинами від 7 м.

Характер просторового розподілу пов'язаний із двома основними чинниками: форма та розміри придатних для заселення ділянок та наявність кормової бази (з високою щільністю дрібних безхребетних). Третій не менш важливий чинник - присутність людини та ступінь іiі втручання [6].

Добова активність зеленої ящірки в значній мірі залежить від температури та освітленості (погода сонячна), та меншою мірою - від вологості. У добових міграціях більш активна молодь, статевозрілі самки мігрують зрідка, самці - різко територіальні [8].

Для розмноження виду характерне утворення факультативних пар, статевозрілі самці мають виражені ревіри, під час шлюбної поведінки зрідка фіксується стратегія сателізму та виявлено самців з невибірковою парувальною поведінкою $[1,4]$.

\section{Висновки}

L. viridis є домінантним видом плазунів на схилах Дністра, його приток, струмків, ярів та балок.

Біотопна приуроченість просторового розподілу популяцій зеленої ящірки підлягає під загальноприйняту типологію:

1) схили горбів та балок 3 густим травостоєм та чагарниками глоду і шипшини (чисельність поселень 30-50 ос./км);

2) ділянки, що пов'язані 3 широколистяними та мішаними лісами - лісові галявини, узлісся, лісові дороги (20-50 ос./км);

3) круті схили ярів, берегові кручі з відслоненнями вапняків 3 трав'янисто-чагарниковою рослинністю (6-11 ос./км).

Просторова структура угруповань $L$. viridis у регіоні переважно агрегаційна й існує в кількох різних формах, що пов'язано з конфігурацією сприятливих ділянок, кормовою базою та міжвидовими стосунками.

1. Зіненко О. І. Плазуни Лівобережного Лісостепу України (поширення, морфологія, таксономія, біологія, екологія) : автореф. дис. ... канд. біол. наук : 03.00.08. Київ, 2006. 21 с.

2. Котенко T. I., Ситнік О. І. Ящірка зелена Lacerta viridis (Laurenti, 1768). Червона книга Украӥни : Тваринний світ / за заг. ред. І. А. Акімова. Київ, 2009. С. 389.

3. Літопис природи Національного природного парку «Дністровський каньйон». 2018. Т. 6. 451 с.

4. Малюк А. Ю. Онтогенетические аспекты формирования межвидовых различий по морфометрическим признакам между прыткой, Lacerta agilis Linnaeus, 1758, и зеленой, L. viridis (Laurenti, 1768), ящерицами (Lacertidae, Sauria, Reptilia). Збірник праџь Зоологічного музею. 2018. № 47. C. $52-65$.

5. Марисова I. В. Земноводні та плазуни північної Тернопільщини. Наукові записки Кременецького педінституту. 1961. №. 6. С. 23-35.

6. Ситнік О. І. Характеристика щільності і структури поселень зеленої ящірки (Lacerta viridis Laurenti, 1768) Придніпровського лісостепу України. Питання степового лісознавства та лісової рекультиваиї̈ земель. 2013. Вип. 42. С. 134-140.

7. Соболенко Л. Ю. Амфібії та рептилії Західного Поділля: фауна, екологія і поширення видів: автореф. дис. ... канд. біол. наук : 03.00.08. Київ, 2010. 24 с.

8. Соболенко Л. Ю. Фауністичні дослідження плазунів Західного Поділля. Науковий вісник НЛТУ Украӥни. 2014. Вип. 6. С. 52-58.

9. Щербак М. М. Кількісний облік земноводних та плазунів: методичні рекомендації щодо проведення моніторингу біологічних об'єктів на заповідних територіях. Київ, 1996. С. 15-17.

10. Assmann O. Protection measures for the Green Lizard - Lacerta viridis (Laurenti, 1768) near Passau (Germany, LowerBavaria). Mertensiella. 2001. N. 13,Rh., 31. P. 251-268.

11. Elbing K. Species protection program «Smaragdeidechse» Lacertaviridis(Laurenti, 1768) in Brandenburg. Mertensiella. 2001. N. 13, Rh., 31. P. 269-278.

24 ISSN 2078-2357. Наук. зап. Терноп. нац. пед. ун-ту. Сер. Біол., 2019, № 2 (76) 
12. Mikatova B. The Lizard, Lacerta viridis (Laurenti, 1768), in the CzechRepublic: Distribution, Ecologyand Conservationaspects. Mertensiella. 2001. N. 13, Rh., 31. P. 138-149.

\section{References}

1. Zinenko O. I. Plazuny Livoberezhnoho Lisostepu Ukrainy (poshyrennia, morfolohiia, taksonomiia, biolohiia, ekolohiia) : avtoref. dys. ... kand. biol. nauk : 03.00.08 Kyiv, 2006. $21 \mathrm{s.}$

2. Kotenko T. I., Sytnik O. I. Yashchirka zelena Lacerta viridis (Laurenti, 1768) . Chervona knyha Ukrainy : Tvarynnyy svit / za zah. red. I. A. Akimova. Kyiv, 2009. S. 389.

3. Litopys pryrody Natsional'noho pryrodnoho parku «Dnistrovs'kyy kan'yon». 2018. T. 6. $451 \mathrm{~s}$.

4. Maliuk A. Iu. Ontogeneticheskie aspekty formirovaniia mezhvidovykh razlichiy po morfometricheskim priznakam mezhdu prytkoy, Lacerta agilis Linnaeus, 1758, i zelenoy, L. viridis (Laurenti, 1768), iashcheritsami (Lacertidae, Sauria, Reptilia). Zbirnik prats' Zoologichnogo muzeiu. 2018. N. 47. S. $52-65$.

5. Marysova I. V. Zemnovodni ta plazuny pivnichnoi Ternopil'shchyny. Naukovi zapysky Kremenets'koho pedinstytutu. 1961. No. 6. S. 23-35.

6. Sytnik O. I. Kharakterystyka shchil'nosti i struktury poselen' zelenoi iashchirky (Lacerta viridis Laurenti, 1768) Prydniprovs'koho lisostepu Ukrainy. Pytannia stepovoho lisoznavstva ta lisovoi rekul'tyvatsii zemel'. 2013. Vyp. 42. S. 134-140.

7. Sobolenko L. Yu. Amfibii ta reptylii Zakhidnoho Podillia: fauna, ekolohiia i poshyrennia vydiv: avtoref. dys. ... kand. biol. nauk : 03.00.08. Kyiv, 2010. 24 s.

8. Sobolenko L. Yu. Faunistychni doslidzhennia plazuniv Zakhidnoho Podillia. Naukovyy visnyk NLTU Ukrainy. 2014. Vyp. 6. S. 52-58.

9. Shcherbak M. M. Kil'kisnyy oblik zemnovodnykh ta plazuniv: metodychni rekomendatsii shchodo provedennia monitorynhu biolohichnykh ob'iektiv na zapovidnykh terytoriiakh. Kyiv, 1996. S. 15-17.

10. Assmann O. Protection measures for the Green Lizard - Lacerta viridis (Laurenti, 1768) near Passau (Germany, LowerBavaria).Mertensiella. 2001. N. 13,Rh., 31. P. 251-268.

11. Elbing K. Species protection program «Smaragdeidechse» Lacertaviridis (Laurenti, 1768) in Brandenburg. Mertensiella. 2001. N. 13, Rh., 31. P. 269-278.

12. Mikatova B. The Lizard, Lacerta viridis (Laurenti, 1768), in the CzechRepublic: Distribution, Ecologyand Conservationaspects. Mertensiella. 2001. N. 13, Rh., 31. P. 138-149.

M. P. Boiko, O. K. Vikyrchak, H. M. Holinei, L. O. Shevchyk

Ternopil Volodymyr Hnatiuk National Pedagogical University, Ukraine

Dniester Canyon National Nature Park, Ukraine

REFERENCE OF STRUCTURE AND ABUNDANCE OF THE GREEN LIZARD (LACERTA VIRIDIS LAURENTI, 1768) POPULATIONS ON THE TERRITORY OF THE NNP «DNIESTER CANYON»

Reliable information about the species composition of the fauna, way of life, abundance, distribution, and breeding features is not only the initial data for in-depth zoological, evolutionary and ecological research, but also the source for nature conservation activity based on the analysis of the state of wildlife resources.

The European green lizard (Lacerta viridis Laurenti, 1768; Reptilia, Squamata) is one of the most vulnerable species of reptiles in the domestic herpetofauna. Therefore, it is the object of ecological research aimed at studying population structure, biotopic distribution, including within the protected natural areas and areas that are undergoing significant anthropogenic transformation.

The work is based on field studies conducted in April - August 2018 and data from the regular phenological observations of the Dniester Canyon National Nature Park.

The current status of the European green lizard population (Lacerta viridis Laurenti, 1768) within the territory of Dniester Canyon National Nature Park has been investigated. The abundance and spatial distribution of the species populations in different biotopes have been studiedon the basis of long-term phenological observations according to the program of the Chronicle of Nature of the National Nature Park and the authors' research. The data of the species occurrence on the territory of the Park for the last six years is given. The abundance of the European green lizard populations under different biotopical conditions and the main factors influencing the studied parameters have been analyzed.

ISSN 2078-2357. Наук. зап. Терноп. нац. пед. ун-ту. Сер. Біол., 2019, № 2 (76) 
The European green lizard has been found to be a stenotopic species that favors only 2-3 biotopes, so it is highly vulnerable due to distortion of specific stations. Besides, L. viridis is the dominant species of reptiles on the Dniester slopes, its tributaries, streams, gullies and ravines.

The biotopes inhabited by this species can be grouped into three main types:

1) slopes of hills and ravines with thick-growing grassand bushes of hawthorn and dog rose (settlement density- 30-50 inhabitants/km);

2) areas related to broad-leaved forests and mixed forests - glades, outskirts of forests, forest roads (20-50 inhabitants/km);

3) steep slopes of gullies, steep bank slopes with limestone outcrops with herbaceous and shrubby vegetation (6-11 inhabitants/km).

The spatial distribution of L. viridis communities in the region is predominantly aggregative and exists in several different forms, which is related to the configuration of favorable plots, the nutritive base and interspecies relationships.

Key words: Lacerta viridis, ecology, population, biotope, Dniester Canyon National Nature Park.

Надійшла 21.05.2019. 